\title{
Chemistry Inspired by the Colors of Fruits, Flowers and Wine
}

\author{
FRANK H. QUINA and ERICK L. BASTOS \\ Departamento de Química Fundamental, Instituto de Química, Universidade de São Paulo, \\ Av. Lineu Prestes, 748, Cidade Universitária, 05508-000 São Paulo, SP, Brazil
}

Manuscript received on June 28, 2017; accepted for publication on August 25, 2017

\begin{abstract}
An overview is provided of the status of research at the frontiers of investigation of the chemistry and photochemistry of two classes of natural plant pigments, the anthocyanins and the betalains, as well as of the pyranoanthocyanin pigments formed from anthocyanins during the maturation of red wine. Together, anthocyanins and betalains are responsible for almost all of the red, purple and blue colors of fruits and flowers and anthocyanins and pyranoanthocyanins are major contributors to the color of red wines. All three types of pigments are cationic below about $\mathrm{pH} 3$, highly colored, non-toxic, reasonably soluble in water or alcohol and fairly stable to light. They exhibit good antioxidant or antiradical activity and, as part of our diet, confer a number of important health benefits. Systematic studies of model compounds containing the basic chromophoric groups of these three types of pigments are providing a deeper understanding of the often complex chemistry and photochemistry of these pigments and their relationship to the roles in vivo of these pigments in plants. These natural pigments are currently being exploited as starting materials for the preparation of novel semi-synthetic dyes, pigments and fluorescence probes.
\end{abstract}

Key words: Anthocyanins, betalains, flowers, plant pigments, wine.

\section{INTRODUCTION}

The colors of fruits and flowers, ranging across the visible spectrum from white to yellow to orange, red, purple or blue (Stournaras et al. 2013), are an integral part of the beauty of nature that we as humans perceive with our limited trichromic (red, green, blue) vision (Cronin et al. 2014, Marshall and Arikawa 2014). Highly efficient pollinators like bees are also trichromic, blind to red, but with visual

Correspondence to: Frank H. Quina

E-mail: quina@usp.br

* Contribution to the centenary of the Brazilian Academy of Sciences. receptors for the ultraviolet (Briscoe and Chittka 2001, Hempel de Ibarra et al. 2014). Less efficient pollinators such as butterflies (Briscoe and Chittka 2001, Arikawa 2017) and hummingbirds (Endler and Mielke Jr 2005) are typically tetrachromic, with vision in the ultraviolet as well as throughout the visible. Despite (or perhaps because of) these differences in visual perception, the colors and the patterns they make on the flower petals, some of which can only be seen by us from photographs in the ultraviolet spectral region (Rørslett 2006, Miller et al. 2011, Garcia et al. 2014), provide contrast against the green-brown background colors of vegetation and can serve as strong visual 
clues for pollinators (Endler and Mielke Jr. 2005, Schoonhoven et al. 2005, Cronin et al. 2014, Hempel de Ibarra et al. 2014, Marshall and Arikawa 2014), which can include pollination-induced color changes as in Tibouchina (Pereira et al. 2011) and other plants (Weiss 1995). Likewise, the colors of fruits that indicate ripeness (Stournaras et al. 2013) attract frugivorous animals that contribute to the spatial dispersion of the seeds of the plant.

Among the natural pigments of fruits and flowers, the anthocyanins and the betalains are particularly noteworthy from the perspective of the range of colors that they are capable of producing in nature as the result of changes in their chemistry. The anthocyanins are widespread in plants and are responsible for most of the red, blue and purple colors of fruits and flowers, in addition to some vegetables (purple varieties of potatoes, corn, beans, onions, carrots, for example, or red cabbage) and some plant leaves (purple trees, the red leaves that surround the small yellow flower of poinsettias, new foliage of many plant species and the red colors of autumn leaves). The betalains range in color from yellow to red-purple, but are restricted to a single order of flowering plants, the Caryophyllales, which includes cacti, bougainvillea, carnations, some carnivorous plants and red and yellow beets. For reasons that are still not yet entirely clear, there is mutual exclusion of anthocyanins and betalains in nature (Gould and Lee 2002, Tanaka et al. 2008, Jain and Gould 2015), i.e., they do not coexist in the same plant species, although betalain formation has been induced artificially in anthocyanin-producing plants (Harris et al. 2012).

Despite their very distinct chemical structures, both anthocyanins and betalains are cationic below about $\mathrm{pH} 3$, water- and alcohol-soluble, highly colored (Shimamoto and Rossi 2015), and reasonably stable to light, though their slow fading or photobleaching in sunlight is the basis of the Anthotype photographic process (Herschel 1842, Fabbri 2012, Coelho 2013). Since they have been consumed in food for millennia, both are generally regarded to be non-toxic and are available for use as natural food colorants in the form of crude extracts from either grape residues from red wine production in the case of anthocyanins or from red beetroot in the case of betalains. Moreover, both have substantial antioxidant or antiradical activity (Gliszczyńska-Świgło et al. 2006, He and Giusti 2010, Bueno et al. 2012a, b, Navas et al. 2012a, b, Lila et al. 2016, Oliveira et al. 2016c, Tománková

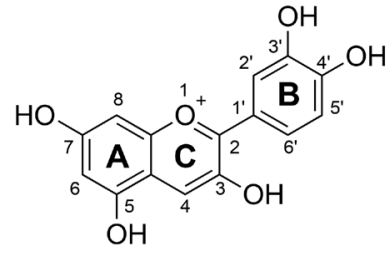

Cyanidin (50\%)<smiles>Oc1cc(O)c2cc(O)c(-c3cc(O)c(O)c(O)c3)[o+]c2c1</smiles>

Delphinidin (12\%)<smiles>Oc1ccc(-c2[o+]c3cc(O)cc(O)c3cc2O)cc1</smiles>

Pelargonidin (12\%)<smiles>COc1cc(-c2[o+]c3cc(O)cc(O)c3cc2O)cc(OC)c1O</smiles>

Malvidin (7\%)<smiles>COc1cc(-c2[o+]c3cc(O)cc(O)c3cc2O)ccc1O</smiles>

Peonidin (12\%)<smiles>COc1cc(-c2[o+]c3cc(O)cc(O)c3cc2O)cc(O)c1O</smiles>

Petunidin (7\%)

Figure 1 - The six most common chemical structures of anthocyanins, shown as the fully deglycosylated or aglycone forms referred to as anthocyanidins; the percentages in parentheses represent the approximate relative natural abundances. 
et al. 2016, Sigurdson et al. 2017, Slimen et al. 2017) and, as part of our diet, can potentially exert a number of important health benefits (He and Giusti 2010, Gengatharan et al. 2015, Gandía-Herrero et al. 2016, Lila et al. 2016, Kay et al. 2017), making their use as substitutes for artificial food dyes particularly desirable (Wrolstad and Culver 2012, Sigurdson et al. 2017).

The anthocyanins are derived biosynthetically from flavonoids (Tanaka et al. 2008) and, although thousands of different anthocyanins have been characterized, almost all can be classified into one of six basic structural types, which differ only in the substitution of hydroxy or methoxy substituents in the $\mathrm{B}$ ring, as shown in Figure 1 for the corresponding deglycosylated or anthocyanidin forms. In nature, the 3-hydroxy group of anthocyanins is always glycosylated, which is apparently important for thermal stability, while the 5-hydroxy group may or may not be glycosylated. Additional structural differences can occur in the glycosylated portions of the anthocyanins and other colorless molecules attached via acyl groups to the sugars, often important for modulation of the color or stability (Castaneda-
Ovando et al. 2009, Raghvendra et al. 2011, SantosBuelga et al. 2014, Trouillas et al. 2016).

The betalains, on the other hand, are Schiff base adducts of betalamic acid (Tanaka et al. 2008), a fluorescent aldehyde derivative of L-tyrosine, with an amino acid or amine (Figure 2). When the amino acid is cyclo-DOPA or a glycosylated derivative thereof, the resultant betalains are reddish-purple in color due to the extended conjugation and designated generically as betacyanins. With other amino acids or amines, the resultant betains are yellow or yelloworange and generically referred to as betaxanthins (Gengatharan et al. 2015, Gonçalves et al. 2015, Khan and Giridhar 2015, Khan 2016, Slimen et al. 2017). This variability of the relative proportions of betacyanins and betaxanthins is responsible for the enormous range of colors of the flowers of bougainvillea vines. The same range of colors could potentially be achieved in food products by mixing the betacyanin extract of red beets with the betaxanthin-rich extract of yellow beets.

In the following sections, we provide an overview of the status of research at the frontiers of the investigation of the chemistry
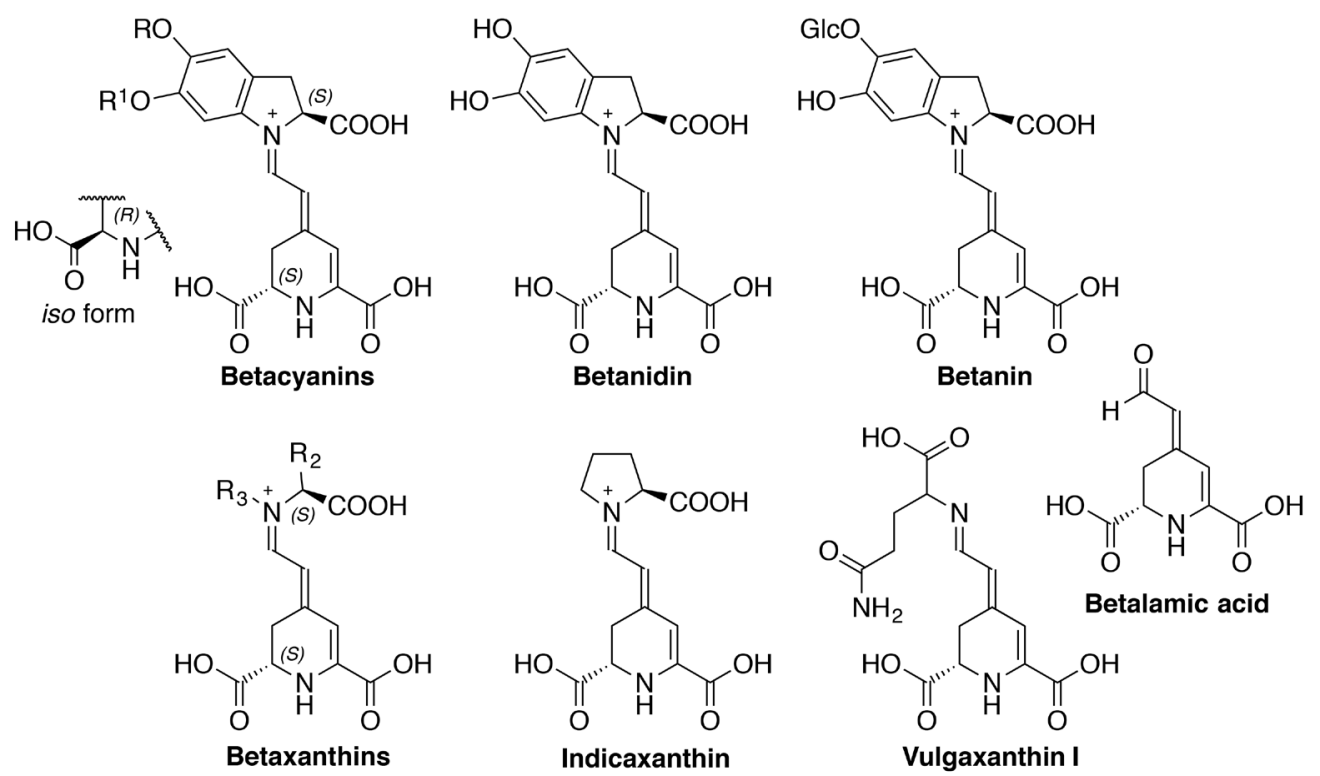

Figure 2 - Generic structures of betacyanins and betaxanthins, their biosynthetic precursor betalamic acid and several examples of naturally occurring betalains. 
and photochemistry of anthocyanins and betalains, as well as the more recent interest in the pyranoanthocyanin pigments that form from anthocyanins during the maturation of red wine. Leading references, with emphasis on recent reviews, are provided for readers desiring more detailed information on the topics addressed in this overview. Note that much of our current understanding of these pigments has been derived from studies of model compounds that mimic the reactivity patterns of the natural pigments, while permitting a greater latitude of structural modification than provided by Nature. These studies have been particularly useful for the elucidation of the relationship between the complex chemistry and photochemistry of these pigments and their biological roles in plants and for the rational design of novel semi-synthetic dyes, pigments and fluorescence probes.

\section{THE ANTHOCYANIN PIGMENTS OF PLANTS}

\section{The ground-state chemistry of Anthocyanins}

Anthocyanin-containing plant extracts have been employed as $\mathrm{pH}$ indicators since at least the seventeenth century (Rancke-Madsen 1972, Terci and Rossi 2002) due to the $\mathrm{pH}$-dependent changes in their color in aqueous solution. These color changes reflect a very rich chemistry (Figure 3 ) involving the interconnected series of reversible $\mathrm{pH}$-dependent equilibria (Castaneda-Ovando et al. 2009, Quina et al. 2009, Rossi and Shimamoto 2010, Salomão et al. 2010, Pina et al. 2012, 2015, Santos-Buelga et al. 2014, Silva et al. 2016) indicated in Figure 3. Below $\mathrm{pH} 3$, the dominant form of anthocyanins in aqueous solution is the red or red-purple 7-hydroxy flavylium cation form, $\mathbf{A H}^{+}$, with a $\mathrm{pK}_{\mathrm{a}}$ for formation of the conjugate base, $\mathbf{A}$, in the range of 4-5 (Freitas et al. 2007, 2011). However, above about $\mathrm{pH} 3$, attack of water at the 2-position of the cationic form $\left(\mathbf{A H}^{+}\right)$of the anthocyanin forms the colorless or pale yellow hemiketal $\mathbf{B}$ (on the time scale of seconds to minutes), resulting in an almost complete loss of the visible color. Subsequent ringopening tautomerism (on the time scale of minutes) produces the colorless or pale yellow (E)-chalcone (EC), which slowly (hours to days) equilibrates with the (Z)-chalcone (ZC).

Although encapsulation (Cavalcanti et al. 2011, Held et al. 2016, Cortez et al. 2017) and copigmentation (Trouillas et al. 2016, Cortez et al. 2017) might be strategies to inhibit the loss of

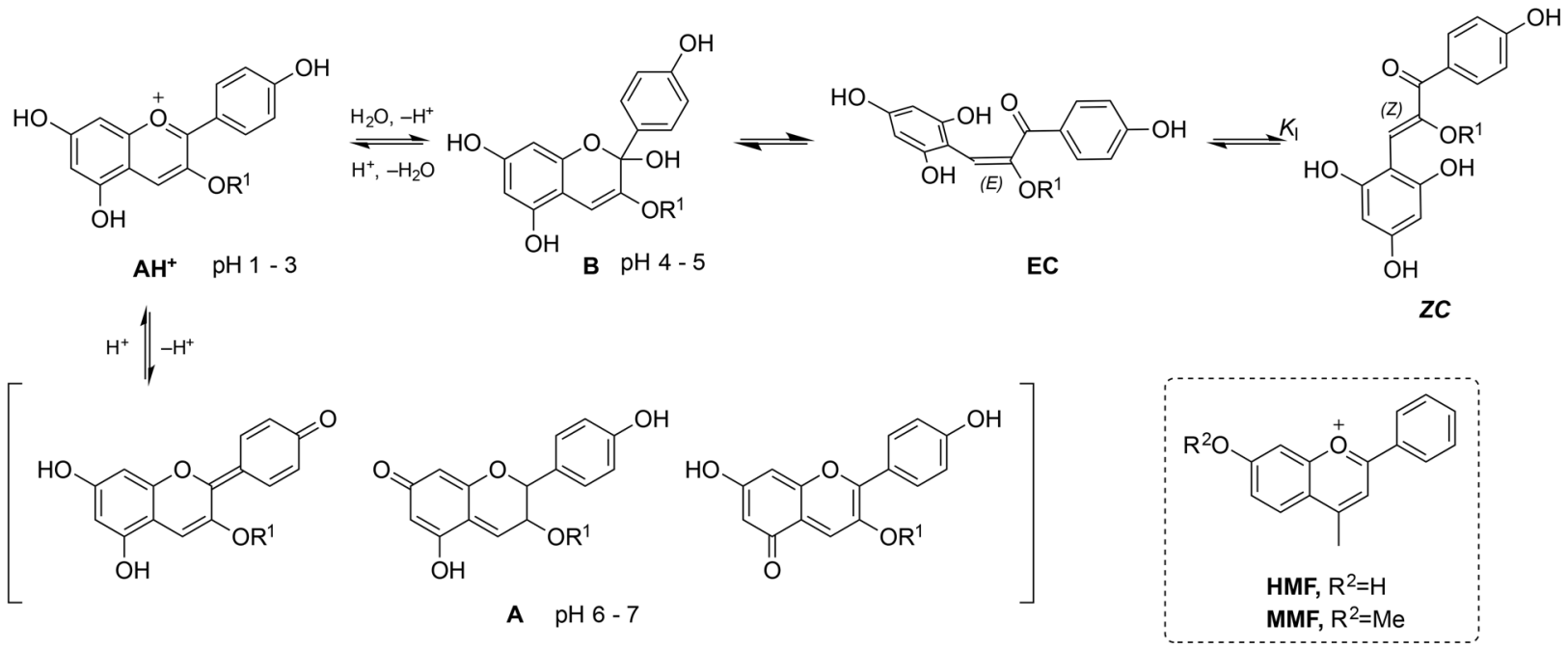

Figure 3 - The pH-dependent multiequilibria of natural anthocyanins, illustrated for pelargonidin monoglyceride $\left(\mathrm{R}^{1}=\right.$ glucosyl moiety), together with the chemical structures of the model flavylium cation analogs HMF and MMF used to investigate aspects of anthocyanin chemistry and photochemistry. 
color, the range of application of anthocyanins as natural food colorants is still currently restricted to relatively acidic media where the cation $\mathbf{A} \mathbf{H}^{+}$ is the dominant species present (Wrolstad and Culver 2012, Sigurdson et al. 2017). On the other hand, by incorporating anthocyanins in an appropriate polymer film matrix, one can fabricate smart food packaging materials that change color due to liberation of amines resulting from the decomposition of food products (Veiga-Santos et al. 2011, Pereira Jr et al. 2015, Maciel et al. 2015).

In nature, the anthocyanins often are present as mixtures of the different basic structures in different degrees of glycosylation etc., which represents a barrier to systematic studies of the chemistry of natural anthocyanins. Fortunately, most of the salient features of the chemistry and photochemistry of naturally-occurring anthocyanins are mimicked by the synthetically more accessible 7-hydroxyflavylium cations (Pina et al. 2012), in which the nature, position and number of other substituents can be varied systematically in order to develop structure-reactivity correlations (Freitas et al. 2011) or alter the net charge or hydrophobicity of the molecule. In addition, some or all of the multiequilibria can be selectively blocked (Quina et al. 2009), as in the 7-hydroxy-4-methyl-flavylium cation (HMF), in which the acid-base equilibrium is preserved but hydration impeded, and the 7-methoxy-4-methyl-flavylium cation (MMF), in which none of the multiequilibria occur (Figure 3).

Photophysics of the electronically excited states of Anthocyanins

In fruits and flowers, it is straightforward to identify the primary biological role of anthocyanins as signals for frugivores or pollinators, respectively, although additional properties such as antioxidant capacity should not be ignored. In plant leaves, however, the biological raison d'être for the presence of anthocyanins has been the subject of discussion for at least a century (Wheldale 1916, Gould and Lee 2002, Landi et al. 2015). Anthocyanins are known to be expressed in newly sprouted leaves and in situations of stress induced by drought, excess solar radiation or physical damage to the plant (Landi et al. 2015), as well as in senescent autumn leaves (Keskitalo et al. 2005). Among the putative explanations, the role of acting as a sunscreen or filter (Solovchenko 2010) to protect the photosynthetic apparatus from excess solar radiation has been advanced most frequently, though several other alternatives have also been seriously considered (Gould and Lee 2002, Landi et al. 2015). Of these, the viability of the photoprotection hypothesis is amenable to testing from a photochemical standpoint. Thus, like any sunscreen molecule, if anthocyanins do indeed function as effective photoprotectors, they must both absorb strongly in the appropriate spectral regions and very rapidly convert the absorb light energy into heat, without producing any net photochemistry or forming undesirable intermediates such as radicals or reactive oxygen species.

Indeed, systematic studies of the photophysics of anthocyanins (Quina et al. 2009, Silva et al. 2016) have shown that, analogous to phenol or naphthol, the singlet excited state of the cationic form, $\mathbf{A} \mathbf{H}^{+*}$, of anthocyanins is a very strong photoacid, with excited state $\mathrm{pK}_{\mathrm{a}}^{*}$ values below 0 , i.e., 5-6 orders of magnitude more acidic than the ground state. Moreover, the time scale of adiabatic proton transfer from $\mathbf{A H}^{+*}$ to water, forming the excited base $\mathbf{A}^{*}$, is extremely short, in the range of 5-20 ps. The excited base is also short lived and decays back to the ground state in ca. 200 ps. Thus, as required for a sunscreen (Kockler et al. 2012, Saewan and Jimtaisong 2015, Rodrigues et al. 2016), excited state proton transfer effectively converts the absorbed light energy into heat in less than a ns, with no other significant competing processes. Other recent studies have shown that the 
singlet excited states of the colorless hemiketal, $\mathbf{B}$, and the chalcones could also serve as effective ancillary sunscreen molecules in the ultraviolet region. The former undergoes photoinduced ring opening tautomerism on a ps timescale, while the chalcones undergo $E-Z$ photoisomerization (Costa et al. 2015).

Given the ultrafast nature of the proton transfer from $\mathbf{A H}^{+*}$ to water, 7-hydroxyflavylium ions have been found to be excellent fluorescence probes for the study of proton dynamics at the surface of micelles and in water-organic solvent mixtures (Quina 2013, Freitas et al. 2014). In these systems, proton transfer followed by geminate recombination between the proton and the newlyformed excited base can be detected and the rate constants for the various primary events of the proton transfer itself, including back transfer and escape of the proton from the geminate pair $\left(\mathrm{A}^{* 1} \bullet \bullet \bullet \mathrm{H}^{+}\right)$can be determined:

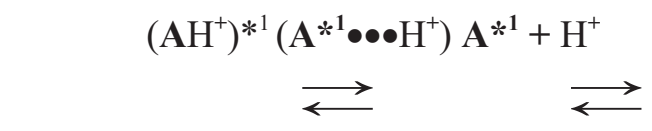

Anthocyanin complexes

In plants, anthocyanins localize in vacuoles where there are also a variety of other organic molecules, metal ions, or biopolymers that can form complexes with the anthocyanins. In some cases, insoluble anthwocyanic vacuolar inclusions are present and may enhance anthocyanin storage (Pourcela et al. 2010). The complexation of anthocyanins with colorless organic molecules (referred to as copigments) increases the stability of the $\mathbf{A} \mathbf{H}^{+}$form and thus the $\mathrm{pH}$ range over which the visible color persists. The driving force for this bimolecular complexation or "copigmentation" involves a significant charge-transfer component (Silva et al. 2005, Quina et al. 2009, Trouillas et al. 2016), in addition to hydrophobic or, in some cases, ion-pairing contributions. These copigmentation complexes are non-fluorescent and the charge- transfer character of the excited state mediates ultra-fast non-radiative decay back to the ground state (Rodrigues et al. 2009, Silva et al. 2016). Hence, copigmentation complexes are even more efficient than uncomplexed anthocyanins, by at least an order of magnitude, at transforming absorbed solar energy into heat. In addition to bimolecular complex formation, many anthocyanins have been characterized in which copigments are covalently attached to the sugar residues of the anthocyanins, resulting in stabilization of the $\mathbf{A} \mathbf{H}^{+}$form via intramolecular copigmentation (Silva et al. 2012, Trouillas et al. 2016).

Gottlieb (1982) pointed out that blue flower color is characteristic of the most highly evolved flowering plants, which should favor pollination by hymenoptera, which do not detect red light. Cyanidin, delphinidin, and petunidin, with orthohydroxy groups in the B-ring, can change color by forming complexes with divalent and trivalent metal cations, notably $\mathrm{Al}^{3+}, \mathrm{Fe}^{2+} / \mathrm{Fe}^{3+}$ and $\mathrm{Mg}^{2+}$, transforming the color of the pigment from red to blue (Yoshida et al. 2009, Castaneda-Ovando 2009, Sigurdson and Giusti 2014, Oyama et al. 2015, Trouillas et al. 2016, Sigurdson et al. 2017, Volodymyr et al. 2017). Japanese (Yoshida et al. 2009, Oyama et al. 2015) and European (Trouillas et al. 2016) groups have conducted detailed experimental and theoretical studies of the various types of blue metal-containing complexes of anthocyanins. Anthocyanins and flavylium ions with ortho-hydroxyl groups in the B-ring also bind to mesoporous $\mathrm{TiO}_{2}$ and have been examined as chromophores in dye-sensitized solar cells, though net efficiencies are still relatively low for all types of natural plant pigment extracts tested thus far (Calogero et al. 2012, 2013, Hug et al. 2014, Jaafar et al. 2017). Although no systematic studies of their photophysics have been reported to date, the preliminary indications are that anthocyaninmetal complexes are probably non-fluorescent and old Japanese woodcut prints colored with the blue 
metaloanthocyanin pigment extracted from the Asiatic dayflower (Commelina communis) must be protected from light to prevent fading (Sasaki and Coombs 2005, Hioki 2009).

\section{THE CHEMISTRY AND PHOTOCHEMISTRY OF BETALAINS}

Unlike anthocyanins, the color of betalains is insensitive to $\mathrm{pH}$ in the range from acid to neutral. This in fact provides a rather simple test for discriminating between these two classes of pigments for red or purple fruits or flowers: the pigments of the fruit or flower of interest are extracted into mildly acidic methanol and the $\mathrm{pH}$ of the extract adjusted to ca. $\mathrm{pH} 7$; a rapid and reversible change of the color or fading indicates that the pigment is an anthocyanin rather than a betalain (Rossi and Shimamoto 2010). In addition, red beetroot serves as a convenient source of appreciable quantities of betanin (Figure 2), which can then be hydrolyzed to betalamic acid (Gonçalves et al. 2012). The betalamic acid thus obtained can then be reacted with amino acids or other aminecontaining compounds to prepare a wide variety of natural and synthetic non-natural analogs of betalains (Schliemann et al. 1999, Gonçalves et al. 2015). The study and characterization of natural and artificial derivatives of betalains suffers from two important limitations, viz., low solubility in non-aqueous media and hydrolytic instability in aqueous media (Slimen et al. 2017). Betalains are chemically labile in highly acidic aqueous media $(\mathrm{pH}<1)$ and alkaline hydrolysis occurs at $\mathrm{pH}>8$, restricting most studies in aqueous media to slightly acidic conditions $(4<\mathrm{pH}<6)$. Even at $\mathrm{pH} 5$, the thermal decomposition of most derivatives occurs in a few minutes at $100{ }^{\circ} \mathrm{C}$. (Herbach et al. 2006, Gonçalves et al. 2013a). Betalains are also subject to metal-ion catalyzed decomposition (Slimen et al. 2017). An additional inconvenience is that water can also catalyze the $\mathrm{E}-\mathrm{Z}$ isomerization of betalains (Bartoloni et al. 2013). Recently, however, it has been found that trifluoroethanol (TFE) and aqueous TFE are particularly interesting solvents for betalains (Bartoloni et al. 2013). TFE improves the hydrolytic stability of betalains, enabling their structural and physicochemical characterization, and TFE may be a useful solvent for the optimization of the synthesis of new betalain derivatives. Encapsulation has also been investigated as a stabilization strategy for betalains (Slimen et al. 2017).

While most betaxanthins are weakly fluorescent in aqueous solution (fluorescence quantum yields typically less than 0.001), betacyanins are essentially non-fluorescent (Gonçalves et al. 2015). The fluorescence quantum yields of betaxanthins and several different synthetic analogs were found to increase 2-4 fold in TFE relative to water, probably reflecting the different influence of intermolecular hydrogen bonding on the nonradiative deactivation of the singlet excited state of the betalain (Bartoloni et al. 2013). Betaxanthins pigments are responsible for the fluorescence of the petals of the flowers of the yellow varieties of four-o'clock (Mirabilis jalapa) and eleveno'clock (Portulaca grandiflora) under illumination with blue light (Gandía-Herrero 2005, Iriel and Lagorio 2010b, Gonçalves et al. 2015). However, this fluorescence, and that of flowers in general, is too weak relative to the light reflected from the flower to be of appreciable importance in attracting pollinators (Iriel and Lagorio 2010a, b).

\section{Selected practical applications of Betalains}

Although naturally-occurring betalains are only weakly or non-fluorescent, betalain analogs with much higher fluorescence efficiencies can be obtained by conjugating betalamic acid with a highly emissive chromophore such as 7-amino4-methylcoumarin (Coumarin 120). The resultant coumarin-containing betalain (cBeet120, Figure 5) not only exhibits good fluorescence and high 
photostability, but also was found to be promising as a dye for the selective live-cell fluorescence imaging of malaria parasites inside Plasmodiuminfected erythrocytes (Gonçalves et al. 2013b). The betalain moiety in cBeet120 extends the pi conjugation of the coumarin chromophore, resulting in a spectroscopically convenient bathochromic spectral shift of the absorption and emission. In addition, compared to the free or unconjugated coumarin, cBeet120 is quite water soluble, which facilitates the accumulation of the dye in the cells. Studies are currently in progress in our laboratories with the objective of delineating the role of the betalain moiety on the selectivity of the uptake by the infected cells and the preferential localization in the parasites.

Metal cations can bind to betalains via complexation with the 1,2,3,4-tetrahydropyridine2,6-dicarboxylic acid moiety of the betalamic acid portion of the molecule. For example, the magentacolored betalain of red beetroot forms a stable orange-colored one-to-one complex with $\mathrm{Eu}^{3+}$. This observation, combined with the knowledge that the causative agent of anthrax, $B$. anthracis, secretes the calcium dipicolinate (CaDPA) complex led to the development of a colorimetric test for anthrax. In the presence of increasing concentrations of
CaDPA in the micromolar range, the color changes from the orange of the $\mathrm{Eu}^{3+}$-betalain complex to magenta due to the competitive binding of $\mathrm{Eu}^{3+}$ to CaDPA rather than to the betalain (Gonçalves et al. 2013c). Compared to the method based on the luminescence of $\mathrm{Eu}^{3+}$ and $\mathrm{Tb}^{3+}$, originally developed by Rosen et al. (1997), our method does not require the synthesis of ligands and has equivalent sensitivity for the detection of CaDPA and bacterial spores since the determining factor in this case is the CaDPA/lanthanide ion competitive binding and not the detection mode.

Betalains also have been used as chromophores in dye-sensitized solar cells (Calogero et al. 2012, Hug et al. 2014, Jaafar et al. 2017), presumably via the interaction of the carboxylate groups of the molecule with the surface of mesoporous $\mathrm{TiO}_{2}$, and for the generation of $\mathrm{H}_{2}$ using nanoparticles decorated with hydrogenase mimic and betanin (Pavliuk et al. 2017a, b). Finally, in a green chemistry application, beetroot extract has been used as both a reducing agent and growth-regulator for the controlled preparation of monodisperse silver nanoparticles in a microfluidic flow system (Fernandes et al. 2016).

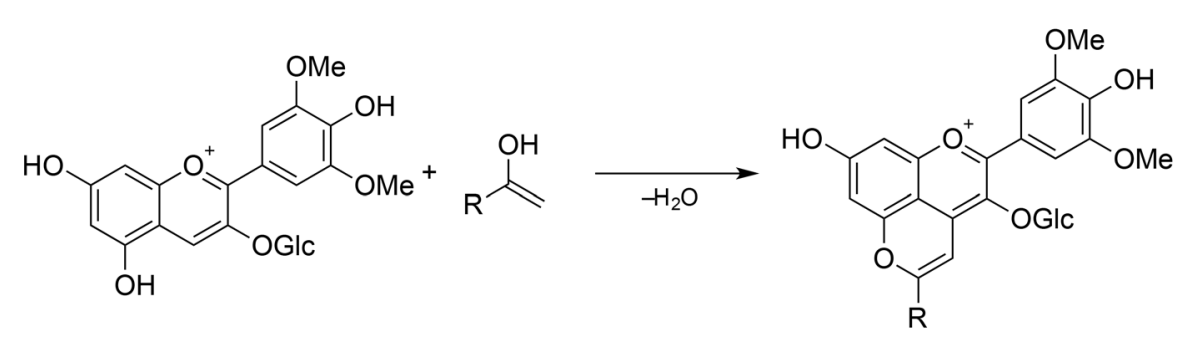

Vitisin B-derived pyranoanthocyanin

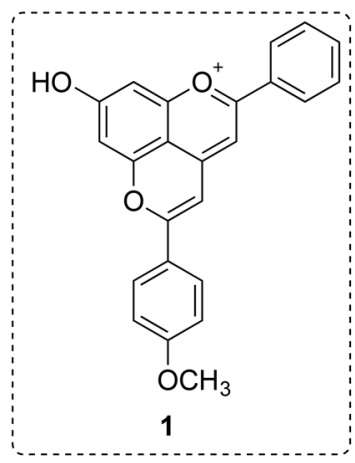

Figure 4 - Formation of a Vitisin B type pyranoanthocyanin via a reaction of malvidin (oenin), the predominant anthocyanin in Vitis vinifera grapes, with the enol form of a copigment during the maturation of red wine (Oliveira et al. 2014; Vallverdú-Queralt et al. 2016), together with the structure of a typical synthetic pyranoflavylium cation 1 (Chassaing et al. 2015) used to investigate the chemistry and photochemistry of the pyranoanthocyanin chromophore (Freitas et al. 2017). 
IMPROVING ON NATURE? THE

PYRANOANTHOCYANINS IN RED WINES

Pyranoanthocyanin pigments formed in vitro from the Anthocyanins in red wines

During the ageing of red wines, the free anthocyanins and/or anthocyanin complexes responsible for the initial color of the wine (Lago-Vanzela et al. 2013, Casassa and Harbertson 2014, Figueiredo-Gonzalez et al. 2014, Heras-Roger et al. 2016, Tang et al. 2017) are slowly transformed by condensation with copigments and yeast metabolites into a variety of more complex pigment molecules (Fulcrand et al. 2006, Marquez et al. 2013, Oliveira et al. 2017b). The condensation products responsible for the final color are primarily the pyranoanthocyanins (Figure 4), which differ from the anthocyanins by the presence of an additional pyran ring situated between the 4-carbon and the 5-hydroxy group of the anthocyanin precursor (Oliveira et al. 2014, Souza et al. 2014).

Due to the presence of the pyranoanthocyanins, the color of mature wines is much more $\mathrm{pH}$-stable (Souza et al. 2014, Oliveira et al. 2014, 2017b) and much less susceptible to bleaching by additives such as sulfite than that of young wines (Marquez et al. 2013, Tománková et al. 2016). Pyranoanthocyanins make an important contribution to the antioxidant radical scavenging capacity of aged wine (Azevedo et al. 2014) and current research is focusing on their contributions to the organoleptic properties of red wines in addition to color (Quaglieri et al. 2016, Garcia-Estevez et al. 2017). As in the case of anthocyanins, pyranoanthocyanin derivatives extracted from wine grapes can act as photosensitizers in solar cells (Santos et al. 2014).

Much of the difficulty in the study of naturallyoccurring pyranoanthocyanins arises from the fact that mature wines can contain a complex mixture of chemically distinct products (Fulcrand et al. 2006, Marquez et al. 2013, Oliveira et al. 2017b). In addition, the entry of beverages containing any amount of alcohol into the IQ-USP for any purpose has been prohibited since 2015 (193 ${ }^{\text {rd }}$ Reunion of the Technical-Administrative Council, IQUSP, 09/21/2015), which precludes the possibility of such studies in our laboratories. As a result, most studies to date, all of which are relatively recent, have employed pyranoflavylium cation analogs (Figure 4) possessing the basic chromophoric group of natural pyranoanthocyanins (Chassaing et al. 2015, Oliveira et al. 2016a, b, 2017a, Vallverdu-Queralt et al. 2016, Freitas et al. 2017). Like pyranoanthocyanins, pyranoflavylium ions are weak acids in the ground state, but have much

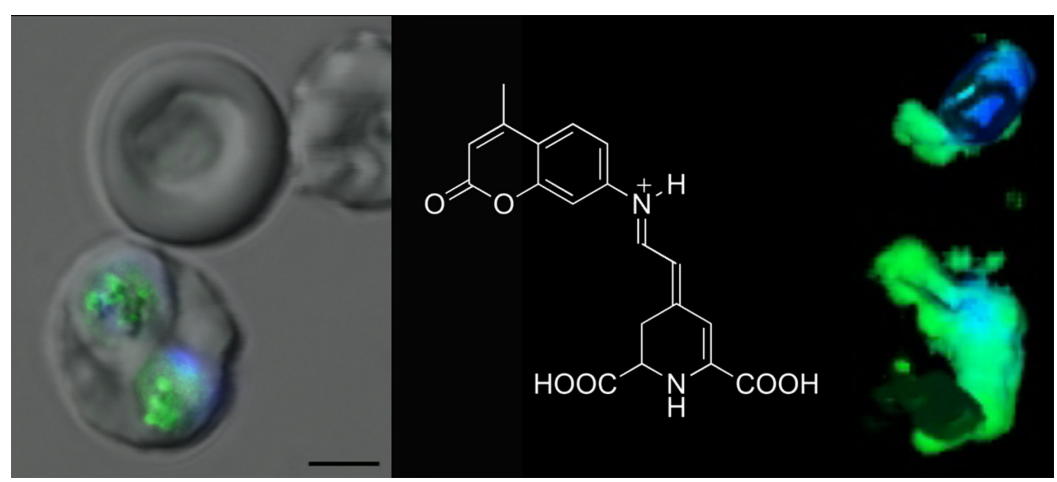

Figure 5 - An example of live cell imaging of Plasmodium-infected red blood cells with cBeet120 (molecular structure indicated in the figure). The blue and green fluorescence emissions are from Hoescht 33342 (a selective stain for DNA) and cBeet120, respectively. 
simpler $\mathrm{pH}$-dependent chemistry, exhibiting only the acid-base equilibrium, with $\mathrm{pK}_{\mathrm{a}}$ values of ca. 4 (Vallverdu-Queralt et al. 2016, Freitas et al. 2017, Oliveira et al. 2017a). The absence of the hydration reaction is responsible for the persistence of the visible color of pyranoanthocyanins at neutral $\mathrm{pH}$ (Oliveira et al. 2014, 2017b, Souza et al. 2014). Although the photoacidity of pyranoflavylium ions is less pronounced than that of uncomplexed anthocyanins and 7-hydroxyflavylium cations, excited state proton transfer does still appear to be the dominant excited state deactivation pathway of pyranoanthocyanins as well, consistent with their relatively good photostability (Freitas et al. 2017).

\section{PERSPECTIVES}

With its enormous biodiversity, Brazilian tropical flora is a treasure-trove of natural plant pigments. Over eons, the evolution of the color of fruits and flowers has resulted in the development of a variety of natural pigments via which plants interact with their environment such as plant-insect or plantherbivore interactions. We have briefly considered here current aspects of research at the frontiers of investigation of the chemistry and photochemistry of the two pigment classes, the anthocyanins and the betalains, that are responsible for almost all of the red, purple and blue colors of fruits and flowers. Elucidation of this often complex chemistry and photochemistry points to strategies for stabilizing the color of these natural pigments in practical applications such as nutraceuticals in foods or dyes in consumer products. At the same time, systematic studies of model compounds containing the basic chromophoric groups of these pigments are providing a deeper understanding of the effects of solvent, substituents, copigmentation and the formation of metal complexes on pigment color and stability, as well as identifying new applications. The development of efficient protocols for inducing the formation in vitro of pyranoanthocyanin pigments analogous to those produced during the maturation of red wines provides an alternative for improving the stability of the color of anthocyanins while maintaining the benefits to human health. Finally, methodologies for the larger-scale isolation of betalains and anthocyanins are paving the way for employing these natural pigments as starting materials for the preparation of novel semisynthetic dyes, pigments and fluorescence probes.

\section{ACKNOWLEDGMENTS}

The authors thank the international collaborators, students and post-doctoral fellows cited in the references to the work from our laboratories. Funding has been provided by the Fundação de Amparo à Pesquisa do Estado de São Paulo (FAPESP, Grant 2016/21445-9 to ELB), Conselho Nacional de Desenvolvimento Científico e Tecnológico (CNPq, Universal grant 408181/2016-3), Instituto Nacional de Ciência e Tecnologia para Catálise em Sistemas Moleculares e Nanoestruturados (INCT-Catálise), Núcleo de Apoio à Pesquisa em Tecnologia Fotoquímica (NAP-PhotoTech) and Coordenação de Aperfeiçoamento de Pessoal de Nível Superior (CAPES), Fundação para a Ciência e a Tecnologia (FCT) Brazil-Portugal international cooperation grants. Both authors thank the $\mathrm{CNPq}$ for productivity fellowships.

\section{REFERENCES}

ARIKAWA K. 2017. The eyes and vision of butterflies. J Physiol 595: 5457-5464.

AZEVEDO J, OLIVEIRA J, CRUZ L, TEIXEIRA N, BRAS NF, FREITAS V AND MATEUS N. 2014. Antioxidant features of red wine pyranoanthocyanins: Experimental and theoretical approaches. J Agr Food Chem 62: 7002-7009.

BARTOLONI FH, GONCALVES LCP, RODRIGUES ACB, DÖRR FA, PINTO E AND BASTOS EL. 2013. Photophysics and hydrolytic stability of betalains in aqueous trifluoroethanol. Monatsh Chem 144: 567-571.

BRISCOE AD AND CHITTKA L. 2001. The evolution of color vision in insects. Ann Rev Entomol 46: 471-510.

BUENO JM, RAMOS-ESCUDERO F, SÁEZ-PLAZA P, MUÑOZ AM, NAVAS MJ AND ASUERO AG. 2012a. 
Analysis and Antioxidant Capacity of Anthocyanin Pigments. Part I: General Considerations Concerning Polyphenols and Flavonoids. Crit Rev Anal Chem 42: 102-125.

BUENO JM, SÁEZ-PLAZA P, RAMOS-ESCUDERO F, JIMÉNEZ AM, FETT R AND ASUERO AG. 2012b. Analysis and Antioxidant Capacity of Anthocyanin Pigments. Part II: Chemical Structure, Color, and Intake of Anthocyanins. Crit Rev Anal Chem 42: 126-151.

CALOGERO G, SINOPOLI A, CITRO I, DI MARCO G, PETROV V, DINIZ AM, PAROLA AJ AND PINA F. 2013. Synthetic analogues of anthocyanins as sensitizers for dye-sensitized solar cells. Photochem Photobiol Sci 12: 883-894

CALOGERO G, YUM JH, SINOPOLI A, DI MARCO G, GRÄTZEL M AND NAZEERUDDIN MK. 2012. Anthocyanins and betalains as light-harvesting pigments for dye-sensitized solar cells. Solar Energy 86: 1563-1575.

CASASSA LF AND HARBERTSON JF. 2014. Extraction, Evolution, and Sensory Impact of Phenolic Compounds During Red Wine Maceration. Ann Rev Food Sci Technol 5: 83-109.

CASTANEDA-OVANDO A, PACHECO-HERNANDEZ ML, PAEZ-HERNANDEZ ME, RODRIGUEZ JA AND GALAN-VIDAL CA. 2009. Chemical studies of anthocyanins: A review. Food Chem 113: 859-871.

CAVALCANTI RN, SANTOS DT AND MEIRELES MAA. 2011. Non-thermal stabilization mechanisms of anthocyanins in model and food systems- An overview. Food Res Internat 44: 499-509.

CHASSAING S, ISOREZ-MAHLER G, KUENY-STOTZ M AND BROUILLARD R. 2015. Aged red wine pigments as a source of inspiration for organic synthesis the cases of the color-stable pyranoflavylium and flavylium-(4 ${ }^{\circledR}$ 8)-flavan chrornophores. Tetrahedron 71: 3066-3078.

COELHO AL. 2013. Antotipia: Processo de Impressão Fotográfica. Dissertação de Mestrado, Programa de PósGraduação em Artes, UNESP, 170 p. Disponível em: https://repositorio.unesp.br/handle/11449/86943 (Acesso em 23/06/2017). (Unpublished).

CORTEZ R, LUNA-VITAL DA, MARGULIS D AND GONZALEZ DE MEJIA E. 2017. Natural Pigments: Stabilization Methods of Anthocyanins for Food Applications. Comp Rev Food Sci Food Saf 16: 180-198.

COSTA D, GALVÃO AM, DI PAOLO RE, FREITAS AA, LIMA JC, QUINA FH AND MAÇANITA AL. 2015. Photochemistry of the hemiketal form of anthocyanins and its potential role in plant protection from UV-B radiation. Tetrahedron 71: 3157-3162.

CRONIN TW, JOHNSEN S, MARSHALL NJ AND WARRANT EJ. 2014. Visual Ecology, Princeton University Press, Princeton, NJ, 432 p.
ENDLER JA AND MIELKE JR PW. 2005. Comparing entire colour patterns as birds see them. Biol J Linnean Soc 86: 405-431.

FABBRI M. 2012. Anthotypes - Explore the darkroom in your Garden and make photographs using plants. Alternative Photography.com: Stockholm, Sweden, 99 p.

FERNANDES DLA, PAUN C, PAVLIUK MV, FERNANDES AB, BASTOS EL AND SÁ J. 2016. Green microfluidic synthesis of monodisperse silver nanoparticles via genetic algorithm optimization. RSC Adv 6: 95693-95697.

FIGUEIREDO-GONZALEZ M, CANCHO-GRANDE B, SIMAL-GANDARA J, TEIXEIRA N, MATEUS N AND FREITAS V. 2014. The phenolic chemistry and spectrochemistry of red sweet wine-making and oakaging. Food Chem 152: 522-530.

FREITAS AA, DIAS LG, MAÇANITA AAL AND QUINA FH. 2011. Substituent effects on the pH-dependent multiequilibria of flavylium salt analogs of anthocyanins. J Phys Org Chem 24: 1201-1208.

FREITAS AA, QUINA FH AND MAÇANITA AA. 2014. Femtosecond and temperature-dependent picosecond dynamics of ultrafast excited-state proton transfer in waterdioxane mixtures. J Phys Chem A 118: 10448-10455.

FREITAS AA, SHIMIZU K, DIAS LG AND QUINA FH. 2007. A computational study of substituted flavylium salts and their quinonoidal conjugate-bases: $\mathrm{S}_{0}{ }^{\circledR} \mathrm{S}_{1}$ electronic transition, absolute $\mathrm{pK}_{\mathrm{a}}$ and reduction potential calculations by DFT and semiempirical methods. J Braz Chem Soc 18: 1537-1546.

FREITAS AA, SILVA CP, SILVA GTM, MAÇANITAAL AND QUINA FH. 2017. From Vine to Wine: Photophysics of a Pyranoflavylium Analog of Red Wine Pyranoanthocyanins. Pure Appl Chem 89: 1761-1767.

FULCRAND H, DUEÑAS M, SALAS E AND CHEYNIER V. 2006. Phenolic Reactions during Winemaking and Aging. Am J Enol Vitic 57: 289-297.

GANDÍA-HERRERO F, ESCRIBANO J AND GARCÍACARMONA F. 2016. Biological Activities of Plant Pigments Betalains. Crit Rev Food Sci Nutri 56: 937-945.

GANDÍA-HERRERO F, GARCÍA-CARMONA F AND ESCRIBANO J. 2005. Floral fluorescence effect. Nature 437: 334.

GARCIA-ESTEVEZ I, CRUZ L, OLIVEIRA J, MATEUS N, FREITAS V AND SOARES S. 2017. First evidences of interaction between pyranoanthocyanins and salivary proline-rich proteins. Food Chem 228: 574-581.

GARCIA JE, GREENTREE AD, SHRESTHA M, DORIN A AND DYER AG. 2014. Flower Colours through the Lens: Quantitative Measurement with Visible and Ultraviolet Digital Photography. PLoS ONE 9: e96646.

GENGATHARAN A, DYKES GA AND CHOO WS. 2015. Betalains: Natural plant pigments with potential application in functional foods. LWT Food Sci Technol 64: 645-649. 
GLISZCZYŃSKA-ŚWIGŁO A, SZYMUSIAK H AND MALINOWSKA P. 2006. Betanin, the main pigment of red beet: Molecular origin of its exceptionally high free radical-scavenging activity. Food Additives Contaminants 23: 1079-1087.

GONÇALVES LCP, DI GENOVA BM, DÖRR FA, PINTO E AND BASTOS EL. 2013a. Effect of dielectric microwave heating on the color and antiradical capacity of betanin. J Food Eng 118: 49-55.

GONÇALVES LCP, MARCATO AC, RODRIGUES ACB, PAGANO APE, FREITAS BC, MACHADO CO, NAKASHIMA KK, ESTEVES LC, LOPES NB AND BASTOS EL. 2015. Betalaínas: das Cores das Beterrabas à Fluorescência das Flores. Rev Virtual Quim 7: 292-309.

GONÇALVES LCP, SILVA SM, DEROSE PC, ANDO RA AND BASTOS EL. 2013c. Beetroot-pigment-derived colorimetric sensor for detection of calcium dipicolinate in bacterial spores. PLoS ONE 8: e73701.

GONÇALVES LCP, TONELLI RR, BAGNARESI P, MORTARA RA, FERREIRA AG AND BASTOS EL. 2013b. A nature-inspired betalainic probe for live-cell imaging of Plasmodium-infected erythrocytes. PLoS ONE 8: e53874.

GONÇALVES LCP, TRASSI MAD, LOPES NB, DÖRR FA, DOS SANTOS MT, BAADER WJ, OLIVEIRA JR VX AND BASTOS EL. 2012. A comparative study of the purification of betanin. Food Chem 131: 231-238.

GOTTLIEB OR. 1982. Micromolecular Evolution, Systematics and Ecology. An Essay into a Novel Botanical Discipline. Springer-Verlag: Berlin, Germany, Chapter 16, p. 142-148.

GOULD KS AND LEE DW. 2002. Anthocyanins in Leaves. Adv Bot Res, Vol 37. Academic Press: New York, 212 p.

HARRIS NN, JAVELLANA J, DAVIES KM, LEWIS DH, JAMESON PE, DEROLES SC, CALCOTT KE, GOULD KS AND SCHWINN KE. 2012. Betalain production is possible in anthocyanin producing plant species given the presence of DOPA-dioxygenase and L-DOPA. BMC Plant Biol 12: 34.

HE J AND GIUSTI MM. 2010. Anthocyanins: Natural Colorants with Health-Promoting Properties. Ann Rev Food Sci Technol 1: 163-187.

HELD B, TANG H, NATARAJAN P, PACHECO DA SILVA C, SILVA VO, BOHNE CAND QUINAFH. 2016. Cucurbit[7] uril inclusion complexation as a supramolecular strategy for color stabilization of anthocyanin model compounds. Photochem Photobiol Sci 15: 752-757.

HEMPEL DE IBARRA N, VOROBYEV M AND MENZEL R. 2014. Mechanisms, functions and ecology of colour vision in the honeybee. J Comp Physiol A 200: 411-433.

HERAS-ROGER J, DÍAZ-ROMERO C AND DARIASMARTÍN J. 2016. What Gives a Wine Its Strong Red Color? Main Correlations Affecting Copigmentation. J Agric Food Chem 64: 6567-6574.
HERBACH KM, STINTZING FC AND CARLE R. 2006. Betalain stability and degradation - Structural and chromatic aspects. J Food Sci 71: 41-50.

HERSCHEL J. 1842. On the Action of the Rays of the Solar Spectrum on Vegetable Colours, and on some new Photographic Processes. Phil Trans Royal Soc 133: 181215.

HIOKI K. 2009. Characteristics of Japanese Block Printed Books in the Edo Period: 1603-1867. The Book and Paper Group Annual 28: 23-29.

HUG H, BADER M, MAIR P AND GLATZEL T. 2014. Biophotovoltaics: Natural pigments in dye-sensitized solar cells. Appl Energy 115: 216-225.

IRIEL A AND LAGORIO MG. 2010a. Implications of reflectance and fluorescence of Rhododendron indicum flowers in biosignaling. Photochem Photobiol Sci 9: 342348.

IRIELAANDLAGORIO MG. 2010b. Is the flower fluorescence relevant in biocommunication? Naturwissenschaften 97: 915-924.

JAAFAR SNH, MINGGU LJ, ARIFIN K, KASSIM MB AND WAN WRD. 2017. Natural dyes as $\mathrm{TIO}_{2}$ sensitizers with membranes for photoelectrochemical water splitting: An overview. Renew Sustain Ener Rev 78: 698-709.

JAIN G AND GOULD KS. 2015. Are betalain pigments the functional homologues of anthocyanins in plants? Environ Experim Bot 119: 48-53.

KAY CD, PEREIRA-CARO G, LUDWIG IA, CLIFFORD MN AND CROZIER A. 2017. Anthocyanins and Flavanones Are More Bioavailable than Previously Perceived: A Review of Recent Evidence. Ann Rev Food Sci Technol 8:155-180.

KESKITALO J, BERGQUIST G, GARDESTRÖM P AND JANSSON S. 2005. A Cellular Timetable of Autumn Senescence. Plant Physiol 139: 1635-1648.

KHAN MI. 2016. Plant Betalains: Safety, Antioxidant Activity, Clinical Efficacy, and Bioavailability. Compr Rev Food Sci Food Saf 15: 316-330.

KHAN MI AND GIRIDHAR P. 2015. Plant betalains: Chemistry and biochemistry. Phytochem 117: 267-295.

KOCKLER J, IEKGEMÖLLER M, ROBERTSON S AND GLASS BD. 2012. Photostability of Sunscreens. J Photochem Photobiol C: Photochem Rev 13: 91-110.

LAGO-VANZELA ES, REBELLO LPG, RAMOS AM, STRINGHETA PC, DA-SILVA R, GARCÍA-ROMERO E, GÓMEZ-ALONSO S AND HERMOSÍN-GUTIÉRREZ I. 2013. Chromatic characteristics and color-related phenolic composition of Brazilian young red wines made from the hybrid grape cultivar BRS Violeta ("BRS Rúbea" × "IAC 1398-21"). Food Res Internat 54: 33-43.

LANDI M, TATTINI M AND GOULD KS. 2015. Multiple functional roles of anthocyanins in plant-environment interactions. Environ Experim Bot 119: 4-17. 
LILA MA, BURTON-FREEMAN B, GRACE N AND KALT W. 2016. Unraveling Anthocyanin Bioavailability for Human Health. Ann Rev Food Sci Technol 7: 375-393.

MACIEL VBV, YOSHIDA CMP AND FRANCO TT. 2015. Chitosan/pectin polyelectrolyte complex as a $\mathrm{pH}$ indicator. Carbohydrate Polym 132: 537-545.

MARQUEZ A, SERRATOSA MP AMD MERIDA J. 2013. Pyranoanthocyanin Derived Pigments in Wine: Structure and Formation during Winemaking. J Chem (Hindawi) 2013: Article ID 713028, 15 p. DOI: 10.1155/2013/713028.

MARSHALL J AND ARIKAWA K. 2014. Unconventional colour vision. Curr Biol 24: R1150-1154.

MILLER R, OWENS SJ AND RØRSLETT B. 2011. Plants and colour: Flowers and pollination. Optics Laser Technol 43: 282-294.

NAVAS MJ, JIMÉNEZ-MORENO AM, BUENO JM, SÁEZPLAZA P AND ASUERO AG. 2012a. Analysis and Antioxidant Capacity of Anthocyanin Pigments. Part III: An Introduction to Sample Preparation and Extraction. Crit Rev Anal Chem 42: 284-312.

NAVAS MJ, JIMÉNEZ-MORENO AM, BUENO JM, SÁEZPLAZA P AND ASUERO AG. 2012b. Analysis and Antioxidant Capacity of Anthocyanin Pigments. Part III: Extraction of Anthocyanins. Crit Rev Anal Chem 42: 313342.

OLIVEIRA J, ARAUJO P, FERNANDES A, BRAS NF, MATEUS N, PINAF AND FREITAS V. 2017a. Influence of the structural features of amino-based pyranoanthocyanins on their acid-base equilibria in aqueous solutions. Dyes Pigments 141: 479-486.

OLIVEIRA J, ARAUJO P, FERNANDES A, MATEUS N AND FREITAS V. 2016a. Synthesis and Structural Characterization of Amino-Based Pyranoanthocyanins with Extended Electronic Delocalization. Synlett 27: 2459-2462.

OLIVEIRA J, FERNANDES A AND FREITAS V. 2016 b. Synthesis and structural characterization by LC-MS and NMR of a new semi-natural blue amino-based pyranoanthocyanin compound. Tetrahedron Lett 57: 1277 1281.

OLIVEIRA J, MATEUS N AND FREITAS V. 2014. Previous and recent advances in pyranoanthocyanins equilibria in aqueous solution. Dyes Pigments 100: 190-200.

OLIVEIRA J, MATEUS N AND FREITAS V. 2017b. WineInspired Chemistry: Anthocyanin Transformations for a Portfolio of Natural Colors. Synlett 28: 898-906.

OLIVEIRA H, WU N, ZHANG Q, WANG J, OLIVEIRA J, FREITAS V, MATEUS N, HE J AND FERNANDES I. 2016c. Bioavailability studies and anticancer properties of malvidin based anthocyanins, pyranoanthocyanins and non-oxonium derivatives. Food Funct 7: 2462- 2468.

OYAMA K, YAMADA T, ITO D, KONDO T AND YOSHIDA K. 2015. Metal Complex Pigment Involved in the Blue
Sepal Color Development of Hydrangea. J Agric Food Chem 63: 7630-7635.

PAVLIUK MV ET AL. 2017a. Hydrogen evolution with nanoengineered $\mathrm{ZnO}$ interfaces decorated using a beetroot extract and a hydrogenase mimic. Sustain Energy Fuels 1: 69-73.

PAVLIUK MV, FERNANDES AB, ABDELAH M, FERNANDES DLA, MACHADO CO, ROCHA I, HATTORI Y, PAUN C, BASTOS EL AND SÁ J. 2017b. Nano-hybrid plasmonic photocatalyst for hydrogen production at $20 \%$ efficiency. Sci Rep 7, 8670. DOI: 10.1038/s41598-017-09261-7.

PEREIRA AC, BERTOLINO DA SILVA J, GOLDENBERG R, MELO GAR AND VARASSIN IG. 2011. Flower color change accelerated by bee pollination in Tibouchina (Melastomataceae). Flora 206: 491-497.

PEREIRA JR VA, QUEIROZ DE ARRUDA IN AND STEFANI R. 2015. Active chitosan/PVA films with anthocyanins from Brassica oleraceae (Red Cabbage) as Time-Temperature Indicators for application in intelligent food packaging. Food Hydrocolloid 43: 180-188.

PINA F, MELO MJ, LAIA CAT, PAROLA AJ AND LIMA JC. 2012. Chemistry and applications of flavylium compounds: A handful of colours. Chem Soc Rev 41: 869-908.

PINA F, OLIVEIRA J AND FREITAS V. 2015. Anthocyanins and derivatives are more than flavylium cations. Tetrahedron 71: 3107-3114.

POURCELA L, IRANIA NG, LUA Y, RIEDL K, SCHWARTZ S AND GROTEWOLD E. 2010. The formation of Anthocyanic Vacuolar Inclusions in Arabidopsis. Molec Plant 3: 78-90.

QUAGLIERI C, IACHETTI G, JOURDES M, WAFFOTEGUO P AND TEISSEDRE PL. 2016. Are pyranoanthocyanins involved in sensory effect in red wines? BIOWeb of Conferences (39th World Congress of Vine and Wine) 7: 02007. DOI: 10.1051/bioconf/20160702007.

QUINA FH. 2013. Dynamics and prototropic reactivity of electronically excited states in simple surfactant aggregates. Curr Opinion Colloid Interface Sci 18: 35-39.

QUINA FH, MOREIRA JR PF, VAUTIER-GIONGO C, RETTORI D, RODRIGUES RE, FREITAS AA, SILVA PF AND MACANITA AL. 2009. Photochemistry of anthocyanins and their biological role in plant tissues. Pure Appl Chem 81: 1687-1694.

RAGHVENDRA, SHARMA V, SHAKYA A, HEDAYTULLAH MD, ARYA GS, MISHRA A, GUPTA AD, PACHPUTE AP AND PATEL D. 2011. Chemical and Potential Aspects of Anthocyanins - A Water Soluble Vacuolar Flavonoid Pigments: A Review. Intern J Pharm Sci Rev Res 6: 28-33.

RANCKE-MADSEN E. 1972. The History of Indicators. In: Bishop E (Ed), Indicators, Pergamon Press: Oxford, UK, p. 1-12. 
RODRIGUES NDN, STANIFORTH M AND STAVROS VG. 2016. Photophysics of sunscreen molecules in the gas phase: a stepwise approach towards understanding and developing next-generation sunscreens. Proc Roy Soc A 472: 20160677.

RODRIGUES RF, DA SILVA PF, SHIMIZU K, FREITAS AA, KOVALENKO SA, ERNSTING NP, QUINA FH AMD MAÇANITA A. 2009. Ultrafast internal conversion in a model anthocyanin-polyphenol complex: implications for the biological role of anthocyanins in vegetative tissues of plants. Chem Eur J 15: 1397-1402.

RØRSLETT B. 2006. Flowers in Ultraviolet Arranged by Plant Family. Website: http://www.naturfotograf.com/ UV_flowers_list.html (Accessed 06/27/2017).

ROSEN DL, SHARPLESS C AND MCGOWN LB. 1997. Bacterial Spore Detection and Determination by Use of Terbium Dipicolinate Photoluminescence. Anal Chem 69: 1082-1085.

ROSSI AV AND SHIMAMOTO GG. 2010. Antocianinas e gelo seco para visualizar equilíbrios ácido/base numa abordagem contextualizada. Educació Química EduQ 7: 31-36.

SAEWAN N AND JIMTAISONG A. 2015. Natural products as photoprotection. J Cosmetic Dermatol 14: 47-63.

SALOMÃO AA, ROSSI AV, ALVES AS, SHIMAMOTO GG, FAVARO MMA AND COELHO TB. 2010. Jogo pedagógico que explora a propriedade indicadora de $\mathrm{pH}$ de extratos de antocianinas de espécies brasileiras. In: Rezende CM and Braibante HTS (Eds), A Química Perto de Você - Experimentos de baixo custo para a sala de aula do Ensino Fundamental e Médio, São Paulo: Sociedade Brasileira de Química, p. 35-43.

SANTOS-BUELGA C, MATEUS N AND FREITAS V. 2014. Anthocyanins. Plant Pigments and Beyond. J Agric Food Chem 62: 6879-6884.

SANTOS CM, GOMES B, GONÇALVES LM, OLIVEIRA J, ROCHA S, COELHO M, RODRIGUES JÁ, FREITAS V AND AGUILAR H. 2014. Pyranoflavylium Derivatives Extracted from Wine Grape as Photosensitizers in Solar Cells. J Braz Chem Soc 25: 1029-1035.

SASAKI S AND COOMBS EI. 2005. Dayflower Blue: Its Appearance and Lightfastness in Traditional Japanese Prints. In: Jett P, Winter J and McCarthy B (Eds), Scientific Research on the Pictorial Arts of Asia. Proceedings of the Second Forbes Symposium at the Freer Gallery of Art, London: Archetype Publications, London, UK, p. 48-57. Available at: https://archive.org/details/ scientificresea00forb (Accessed on 06/27/2017).

SCHLIEMANN W, KOBAYASHI N AND STRACK D. 1999. The Decisive Step in Betaxanthin Biosynthesis is a Spontaneous Reaction. Plant Physiol 119: 1217-1232.
SCHOONHOVEN LM, VAN LOON JJA AND DICKE M. 2005. Insect-Plant Biology. Oxford: Oxford University Press, Oxford, UK, 421 p.

SHIMAMOTO GG AND ROSSI AV. 2015. An artistic introduction to anthocyanin inks. Science in School 31: 32-35.

SIGURDSON GT AND GIUSTI MM. 2014. Bathochromic and Hyperchromic Effects of Aluminum Salt Complexation by Anthocyanins from Edible Sources for Blue Color Development. J Agric Food Chem 62: 6955-6965.

SIGURDSON GT, ROBBINS RJ, COLLINS TMAND GIUSTI MM. 2017. Spectral and colorimetric characteristics of metal chelates of acylated cyanidin derivatives. Food Chem 221: 1088-1095.

SIGURDSON GT, TANG P AND GIUSTI MM. 2017. Natural Colorants: Food Colorants from Natural Sources. Annu Rev Food Sci Technol 8: 261-280.

SILVAPF, LIMAJC, FREITAS AA, SHIMIZU K, MAÇANITA AL AND QUINA FH. 2005. Charge-transfer complexation as a general phenomenon in the copigmentation of anthocyanins. J Phys Chem A 109: 7329-7338.

SILVA PF, PAULO L, BARBAFINA A, ELISEI F, QUINA FH AND MAÇANITA AL. 2012. Photoprotection and the photophysics of acylated anthocyanins. Chem A European J 18: 3736-3744.

SILVA, VO, FREITAS A, MAÇANITA AL AND QUINA FH. 2016. Chemistry and photochemistry of natural plant pigments: The anthocyanins. J Phys Org Chem 29: 594599.

SLIMEN IB, NAJAR T AND ABDERRABBA M. 2017. Chemical and Antioxidant Properties of Betalains. J Agric Food Chem 65: 675-689.

SOLOVCHENKO A. 2010. Photoprotection in Plants. Optical Screening-based Mechanisms. Springer Series in Biophysics 14. Springer Verlag: Berlin, 168 p.

SOUZA A, CABRITA L, ARAÚJO P, MATEUS N, PINA F AND FREITAS V. 2014. Color stability and spectroscopic properties of deoxyvitisins in aqueous solution. New J Chem 38: 539-544.

STOURNARAS KE, LO E, BÖHNING-GAESE K, CAZETTA E, DEHLING DM, SCHLEUNING M, STODDARD MC, DONOGHUE MJ, PRUM RO AND SCHAEFER HM. 2013. How colorful are fruits? Limited color diversity in fleshy fruits on local and global scales. New Phytol 198: 617-629.

TANAKAY, SASAKI NAND OHMIYAA. 2008. Biosynthesis of plant pigments: anthocyanins, betalains and carotenoids. Plant J 54: 733-749.

TANG K, LIU T, HAN Y, XU Y AND LI JM. 2017. The Importance of Monomeric Anthocyanins in the Definition of Wine Colour Properties. S Afr J Enol Vitic 38: 1-10.

TERCI DBL AND ROSSI AV. 2002. Indicadores Naturais de pH: Usar Papel ou Solução? Quím Nova 25: 684-688. 
TOMÁNKOVÁ E, BALÍK J, SOURAL I, BEDNÁR P AND PAPOUŠKOVÁ B. 2016. Colour and Antioxidant Properties of Malvidin-3-glucoside and Vitisin A. Acta Alimentaria 45: 85-92.

TROUILLAS P, SANCHO-GARCÍA JC, FREITAS V, GIERSCHNER J, OTYEPKA M AND DANGLES O. 2016. Stabilizing and Modulating Color by Copigmentation: Insights from Theory and Experiment. Chem Rev 116: 4937-4982.

VALLVERDU-QUERALT A ET AL. 2016. p-Hydroxyphenylpyranoanthocyanins: An Experimental and Theoretical Investigation of Their Acid-Base Properties and Molecular Interactions. Int J Molec Sci 17: 1842, 19 p.

VEIGA-SANTOS R, DITCHFIELD C AND TADINI CC. 2011. Development and evaluation of a novel $\mathrm{pH}$ indicator biodegradable film based on cassava starch. J Appl Polym Sci 120: 1069-1079.
VOLODYMYR S, FEDENKO VS, SHEMET AS AND LANDI M. 2017. UV-vis spectroscopy and colorimetric models for detecting anthocyanin-metal complexes in plants: An overview of in vitro and in vivo techniques. J Plant Physiol 212: 13-28.

WEISS MR. 1995. Floral Color Change: A Widespread Functional Convergence. Am J Bot 82: 167-185.

WHELDALE M. 1916. The Anthocyanin Pigments of Plants. Cambridge University Press: Cambridge, UK, 344 p. Public Domain book available at: https://archive. org/details/anthocyaninpigme00onsl (Accessed on 06/26/2017).

WROLSTAD RE AND CULVER CA. 2012. Alternatives to Those Artificial FD\&C Food Colorants. Annu Rev Food Sci Technol 3: 59-77.

YOSHIDA K, MORI M AND KONDO T. 2009. Blue flower color development by anthocyanins: from chemical structure to cell physiology. Nat Prod Rep 26: 884-915. 